\title{
HET GEZAG VAN DE SCHRIFT
}

\section{IRIE VERSCHILIENDE SCHRIFTBESCHOUWINGEN}

In de grond van de zaak zijn er maar drie verschillende Schriftbeschouwingen en alle drie hebben ze een overeenkomstige opvatting van het gezag der Schrift.

In de eerste plaats is er de oude vrijzinnige Schriftbeschouwing. Hier wordt de Bijbel als een puur menselijk boek beschouwd. $\mathrm{Hij}$ is het verslag van de religieuze ervaringen, die sommige gelovigen in het verleden hadden. Vooral in Israel en later in de Christelijke kerk waren er personen, die diepe religieuze ervaringen hadden en een opmerkelijk inzicht in het wezen en het handelen van God. Die ervaringen en dat inzicht hebben ze neergelegd in hun geschriften. Vanwege de diepte van deze ervaringen zijn deze geschriften nog altijd van grote betekenis voor de latere geslachten. In zekere zin zijn ze gezaghebbend. Maar dan moeten we er onmiddellijk aan toevoegen, dat dit gezag natuurlijk van beperkte en relatieve aard is. Het is wel creatief en stimulerend, maar het moet altijd getoetst worden aan onze eigen ervaringen en inzichten. M.a.w., het is en blijft puur subjectief en het is nooit finaal. Finaal is uiteindelijk alleen maar wat ik zelf ervaar. J. I. Packer vat het zo samen: „All the many varieties (of Liberalism) spring from a single principle, namely, that the final authority for my faith and life is the verdict of my reason, conscience or religious sentiment (subjectivists vary in the way they put this) as I examine Scripture 'with an open mind' (i.e., without presupposing that its own account of itself is true), and measure it by what I have learned from other sources, historical, philosophical, religious and scientific. What under these circumstances reason and conscience say, what I find that 'I feel', that God says".'

In die tweede plaats is er de neo-orthodoxe, en tot op zekere hoogte ook de neo-liberale Schriftbeschouwing. We kunnen het ook anders zeggen: de visie van Karl Barth en tot op zekere hoogte ook die van Rudolf Bultmann en zijn school. Volgens deze opvatting is de Bijbel ook een door en door menselijk boek. Toch is deze opvatting anders dan die van de oude vrijzinnigheid. De Bijbel is niet alleen maar een verslag van subjectieve menselijke ervaringen, maar hij is allereerst het getuigenis van Gods openbaring in Jezus Christus. Als ,getuigenis' is hij een puur menselijk boek. Hij is feilbaar en bevat vele fouten en vergissingen, niet alleen op het terrein van de feiten, maar zelfs op het terrein van theologische interpretatie en evaluatie. ${ }^{2}$ En toch moeten we tegelijk ook zeggen, dat, wanneer Gods Geest dit getuigenis gebruikt en op ons toepast, het het Woord of God voor ons wordt. Dan word dit getuigenis Gods openbaring aan ons.

Wat het gezag van de Schrift betreft, betekent dit dat het zowel relatief als absoluut is. Aan de ene kant is het relatief. Als een 
menselijk getuigenis kan het gezag niet meer dan relatief zijn. Als menselijk document mag de Schrift vrijelijk bekritiseerd worden. Op dit punt zijn Barth en Bultmann het geheel met elkaar eens. In de practijk zijn er natuurlijk grote verschillen. Ieder, die wel eens in de Kirchliche Dogmatik van Barth gelezen heeft, weet, dat Barth maar hoogst zelden de Bijbel openlijk bekritiseren zal. Bultmann daarentegen gaat heel erg ver, zoals bekend is uit zijn, Entmythologisierungsprogram'. Gebruik makend van de ,formgeschichtliche' methode onderwerpt hij de Evangelien aan een diepgaande kritiek en in vele gevallen blijft er heel weinig over van de originele tekst. Toch zijn Barth en Bultmann het in principe eens: de Bijbel mag en moet blootgesteld worden aan onze moderne kritische methoden. Toch zegt Barth ook (en dat is de andere kant van de medaille), dat wanneer het God behaagt om door dit getuigenis tot ons te spreken, er werkelijk openbaring plaats vindt. Op dat moment spreekt God tot ons en dan heeft deze zelfde Bijbel natuurlijk absoluut gezag. Alan Richardson, die zelf deze visie deelt, zegt het zo in zijn Preface to Bible Study: ,Then I recognize that God's message has been sent into the world with my name and address on it. The authority of the Bible means for me that God's message claims me, my obedience and faith: I must listen to what God says and hasten to direct my life in accordance with his will"."

Tenslotte is er de orthodoxe of klassieke Schriftbeschouwing. Volgens deze beschouwing is de Bijbel het Woord van God. Natuurlijk moeten we hier onmiddellijk aan toevoegen, dat hij het Woord van God is in de woorden van mensen. De Bijbel is niet, zoals de Moslims van hun Koran geloven, zo maar uit de hemel gevallen. En toch is het waar, dat we mogen zeggen, dat in deze menselijke woorden God zelf tot ons spreekt. Zoals Calvijn zegt in zijn Institutie: De Bijbel is Deus loquens. Niemand heeft deze opvatting misschien duidelijker en scherpzinniger verdedigd dan $B$. B. Warfield, althans in de Engelssprekende wereld. De Bijbel is niet „man's report to us of what God says, but the very word of God itself, spoken by God himself through human lips and pens". Hij is "the very Word of God, instinct with divine life from the 'in the beginning' of Genesis to the 'Amen' of the Apocalypse - breathed into by God and breathing out God to every devout reader". Dit was de visie van Christus zelf en ook van zijn apostelen. Men vindt ze overal in het Nieuwe Testament, wanneer er van het Oude Testament gesproken wordt. Het is ,, a misapprehension that the Bible witnesses to its plenary inspiration only in a text here and there..., such as our Saviour's declaration that the Scriptures cannot be broken; or Paul's, that every scripture is inspired of God; or Peter's, that the men of God spake as they were moved by the Holy Ghost... These are but the culminating passages of a pervasive testimony to the divine character of Scripture which fills the whole New Testament; and which includes not only such direct assertions of divinity and infallibility for Scripture as these, but, along with them, an endless variety of expressions of confidence in, and phenomena of use of Scripture which are irresistible in their teaching 
when it is once fairly apprehended": Warfield noemt dan de volgende feiten: de verheven namen die aan de Schrift gegeven worden en waarmee ze wordt aangeduid in citaten (zoals: ,de Schrift', ,de Schriften' en ,woorden Gods' (Engels: ,the oracles of God')); de formules die voor citaten gebruikt worden (zoals: ,er staat geschreven', ,er wordt gezegd', ,God zegt'); wanneer uit de wijze van citeren blijkt, dat voor de auteur ,de Schrift zegt' gelijk staat aan, God zegt', of wanneer zelfs verhalende gedeelten onmiddellijk aan God zelf toe worden geschreven; het toeschrijven van Goddelijke eigenschappen aan de Schrift (wanneer bv. gezegd word dat ,de Schrift voorzag'); het noemen van de Heilige Geest als de auteur van een passage of van de hele Schrift, terwijl de menselijke auteur bijna geheel verwaarloosd word; "the reverence shown, and the significance and authority ascribed, to the very words of Scripture; and the general attitude of entire subjection to every declaration of Scripture of whatever kind, which characterizes every line of the New Testament". Het bewijsmateriaal is zo overvloedig, dat het onmogelijk is om het te weerleggen of het weg te redeneren. We kunnen misschien een paar teksten hier en daar weg-verklaren, maar dat helpt weinig. "There are scores, hundreds of them; and they come bursting upon us in one solid mass. Explain them away? We should have to explain away the whole New Testament".'

We noemden dit de orthodoxe of klassieke Schriftbeschouwing. Het kan immers niet ontkend worden, dat deze opvatting door de hele kerk aanvaard en vastgehouden is tot aan de $18 \mathrm{de}$ eeu toe, toen de zgn. Schriftkritiek haar intree deed en theologen begonnen te zeggen, dat dit helemaal niet door de Schrift zelf geleerd werd. Het zou maar een Christelijk overblijfsel zijn van de oude Joodse visie uit de tijd van de apostelen, maar de apostelen zelf, om van Christus helemaal maar niet te spreken, zouden deze opvatting beslist niet gedeeld hebben. Sommigen vonden het wel wat moeilijk om dit vol te houden en zochten een oplossing in de zgn. accommodatie theorie. Maar al deze pogingen en oplossingen waren niets anders dan excuses om eigen kritische opvattingen in overeenstemming met de Bijbel te brengen, of misschien nog beter: om de Bijbel in overeenstemming te brengen met de nieuwe kritische opvattingen. Het is een onomstotelijk feit, dat door de eeuwen heen de kerk altijd de orthodoxe visie heeft gehuldigd. Warfield noemt verschillende namen, zoals die van Origines, Irenaeus, Polycarpus, Augustinus, Luther, Calvijn, Rutherford, Baxter, Charles Hodge, H. B. Smith. Hij had gemakkelijk de hele Gereformeerde traditie in Nederland er bij kunnen noemen (Kuyper, Bavinck, Grosheide, Aalders, J. Ridderbos, G. C. Berkouwer, H. N. Ridderbos, A. D. R. Polman, e.a.). Hij had ook de hele Rooms-Katholieke Kerk er bij kunnen noemen. Dit is immers ook de opvatting van Rome. Nog op het laatste concilie is het opzettelijk en duidelijk herhaald in de Dogmatische Constitutie ,De Revelatione': „The divinely revealed realities, which are contained and presented in the text of sacred Scripture, have been written down under the inspiration 
of the Holy Spirit. For holy Mother Church relying on the faith of the apostolic age, accepts as sacred and canonical the books of the Old and the New Testaments, whole and entire, with all their parts, on the grounds that, written under the inspiration of the Holy Spirit (cf. John $20: 31 ; 2$ Tim. $3: 16 ; 2$ Pet. $1: 19-21 ; 3: 15$, 16), they have God as their author, and have been handed on as such to the Church herself" (section 11).

Zij, die deze Schriftbeschouwing hebben, hebben natuurlijk ook een overeenkomstige opvatting van het gezag der Schrift. Ze geloven allemaal, dat de Schrift goddelijk gezag heeft. Hier spreekt God Zelf tot ons. Als de Bijbel iets zegt, zegt God dit en wij hebben het te aanvaarden in gehoorzaamheid en onderwerping. - Dit is inderdaad de visie van die R.K. Kerk en van de Reformatie.

\section{Rome - Reformatie}

Met opzet noemen we telkens Rome en de Reformatie in een adem. Het kan immers niet ontkend worden, dat ze tot op dit punt het volkomen met elkaar eens zijn. Helaas moeten we de nadruk leggen op de woorden: ,tot op dit punt'. Zodra we verder gaan, zien we dat ze uitelkaar gaan. Ja, na een poosje wordt de scheiding zo groot dat ze tegenover elkaar komen te staan en dat ze zelfs nauwelijks in staat zijn elkaar nog te herkennen. Want wat gebeurt er in het geval van Rome? Het voegt twee andere autoriteiten toe aan de Schrift.

a) De mondelinge overlevering. Deze toevoeging is al nadrukkelijk vastgelegd door het Concilie van Trente. Nadat eerst gezegd is, dat het Evangelie de bron van alles is, nl. zowel van de heilswaarheid als van de moraal, wordt verklaard dat deze waarheid en moraal ,are contained in the written books and the unwritten traditions... Following the examples of the orthodox Fathers, (the Synod) receives and venerates with an equal affection of piety and reverence, all the books of the Old and the New Testament... as also the said traditions, as well those appertaining to faith as to morals, as having been dictated, either by Christ's own word of mouth, or by the Holy Ghost and preserved in the Catholic Church by a continuous succession". "In de laatste jaren is er veel discussie geweest over de vraag of er dus een of twee bronnen der openbaring zijn. Zijn Schrift en traditie twee afzonderlijke bronnen, of is de Schrift de enige bron en is de traditie niets meer dan de kerkelijke interpretatie van en het kerkelijke kommentaar op deze openbaring in de Schrift? Het tweede Vaticaanse Concilie heeft geweigerd hier een keuze te doen, maar het heeft geen twijfel gelaten over de vraag of er een doorgaande stroom van traditie naast het geschreven Woord is. De ,Constitutio de Revelatione' zegt: „Sacred Tradition and sacred Scripture... are bound closely together, and communicate one with the other. For both of them, flowing out from the same divine well-spring, come together in some fashion to form one thing, and move towards the same goal. 
Sacred Scripture is the speech of God as it is put down in writing under the breath of the Holy Spirit. And Tradition transmits in its entirety the Word of God which has been entrusted to the apostles by Christ the Lord and the Holy Spirit. It transmits it to the successors of the apostles so that, enlightened by the Spirit of truth, they may faithfully preserve, expound and spread it abroad by their preaching. Thus it comes about that the Church does not draw her certainty about all revealed truths from the holy Scriptures alone. Hence, both Scripture and Tradition must be accepted and honoured with equal feelings of devotion and reverence" (section 9). ${ }^{10}$ Men lette er op, dat de laatste zin een citaat uit het besluit van Trente is. Op dit punt althans is er niets veranderd bij Rome sinds Trente.

b) Het leergezag van het Magisterium. Rome gelooft, dat God het recht en de mogelijkheid van authentieke en onfeilbare interpretatie van de Schrift aan het Magisterium heeft gegeven. Vaticanum I heeft dit vastgelegd in het dogma van de onfeilbaarheid van de Paus. Als de Paus, ex cathedra', in zijn officiele capaciteit als Opperherder der kerk, een uitspraak doet in zake geloof of moraal, ontvangt hij een speciale assistentie van de Heilige Geest, waardoor zijn uitspraak onfeilbaar is en ,irreformabilis'. In enigzins andere bewoordingen is dezelfde leer herhaald door Vaticanum II in de Constitutie over de Kerk (sectie 25). De Constitutie heeft er zelfs nadrukkelijk aan toegevoegd, dat de uitspraken van de Paus ,are in no way in need of the approval of others, and do not admit of appeal to any tribunal". In de ,Constitutio de Revelatione' lezen we dan nog: „The task of giving an authentic interpretation of the Word of God, whether in its written form or in the form of Tradition, has been entrusted to the living teaching office of the Church alone. The authority in this matter is exercised in the name of Jesus Christ" (sectie 10). Wel wordt daar onmiddellijk aan toegevoegd: „Yet this Magisterium is not superior to the Word of God, but is its servant. It teaches only what has been handed on to it. At the divine command and with the help of the Holy Spirit, it listens to this devotedly, guards it with dedication and expounds it faithfully. All that it proposes for belief as being divinely revealed its drawn from this single deposit". Hier hebben we het zgn. dienstknecht-motief, dat zoveel naar voren komt in moderne ecclesiologieën." Maar wat betekent het in werkelijkheid? Wat betekent het, als we denken aan de Mariologische dogmas of het dogma van de onfeilbaarheid van de Paus, dogmas die we helemaal niet in de Schrift kunnen terugvinden en die zelfs niet in de oude mondelinge traditie te vinden zijn? Is het in het licht van deze feiten eigenlijk wel meer dan een lege bewering?

De laatste alinea van dezelfde sectie luidt: „It is clear, therefore, that, in the supremely wise arrangement of God, sacred Tradition, sacred Scripture and the Magisterium of the Church are so connected and associated that one of them cannot stand without the other. Working together, each in its own way under the action of the one Holy Spirit, they all contribute effectively to the salvation 
of souls". In deze correlatie van traditie, Schrift en Magisterium staat het hele probleem levensgroot voor ons. Het Magisterium is de laatste in de trits, maar omdat het de bewaarder en onfeilbare vertolker is van de eerste twee, heeft het uiteindelijk toch het laatste woord, en zo worden de andere twee, met inbegrip van de Schrift zelf, tenslotte toch onderhorig aan het Magisterium. De laatste en finale authoriteit, tegenover wie geen hoger beroep meer mogelijk is, zelfs niet op de Schrift, is de kerk zelf. En zo staan we als Christenen van de Reformatie nog tegenover Rome. Hoewel we allemaal de Bijbel als gezaghebbend aanvaarden en allemaal van het Goddelijk gezag van de Schrift spreken, is er toch een wereld van verschil. Door de traditie aan de Schrift toe te voegen en door aan het Magisterium het recht van onfeilbare en authentieke interpretatie te geven, heeft Rome het gezag van de Schrift zozeer verzwakt, dat op bepaalde punten, zelfs op zeer beslissende punten, de Schrift niet meer met gezag kan spreken. De Schrift is niet meer het ,tegenover' van de kerk, maar ergens staat ze ook ,onder' de kerk. ${ }^{12}$

\section{Inspiratiebeschouwingen}

Zoals we eerder gezien hebben, zijn er in feite maar drie verschillende Schriftbeschouwingen en alle drie hebben ze een verschillende opvatting van het gezag der Schrift. Achter deze drie Schriftbeschouwingen liggen ook drie verschillende visies op de inspiratie der Schrift.

a. Voor het oude Liberalisme is inspiratie op zijn hoogst een vorm van illuminatie door de Heilige Geest. Hoewel meestal wel wordt toegegeven, dat in het geval van de Bijbelschrijvers deze illuminatie ,hoger' is dan de illuminatie, die aan de gewone gelovigen geschonken wordt, is het toch niet meer dan een gradueel verschil. Het blijft allemaal op het subjectieve niveau, omdat we geen enkel middel hebben om het te toetsen of te controleren, afgezien van onze eigen ervaring, die uiteindelijk ook subjectief is. Bovendien is het meer een inspiratie van de persoon van de schrijver dan van het boek, dat hij schrijft. Van het boek kan men alleen maar zeggen, dat het geinspireerd is, omdat het ons inspireert. John Huxtable wijst er ergens op, dat dit alles waar mag zijn voor het persoonlijk geestelijk leven van een gelovige, maar ,it can never serve as a satisfactory doctrine of inspiration. It does not satisfactorily describe or safeguard the uniqueness of the Bible. It is not sufficiently concerned with the truth of what the Bible proclaims and conveys".

b. In de Neo-orthodoxie is inspiratie een actie van de Heilige Geest, die in twee fasen plaats vindt. In de eerste plaats is er de werking van de Heilige Geest op de oorspronkelijke schrijvers. Hoewel ze echte auteurs waren en als zodanig spraken binnen hun eigen psychologische, biologische en historische mogelijkheden, was hun werk toch tegelijkertijd omringd door de Heilige Geest. 
Door Hem werden ze a.h.w. aangedreven en ze stonden onder zijn controle. Maar dit is alleen maar de eerste fase. $\mathrm{Er}$ is nog een tweede fase, die men de eigenlijke daad der inspiratie zou kunnen noemen, nl. wanneer de boeken worden gelezen of gehoord. Karl Barth, de ,vader' der Neo-orthodoxie zegt het zo: „Die Theopneustie der Bibel...., die Gehorsamstellung, in der sie geschrieben ist, die zwingende Tatsache, dasz hier wahre Menschen im Namen des wahren Gottes zu uns reden, sie - und in ihr besteht dieses Wunder - liegt nicht vor uns, indem die Bibel vor uns liegt und indem wir die Bibel lesen. Die Theopneustie ist der Akt der Offenbarung, in welchem die Propheten und Apostle in ihrer Menschlichkeit wurden, was sie waren, und in dem allein sie in ihrer Menschlichkeit auch uns werden können, was sie sind". "Even verder schrijft hij: „,Der Kreis, der von den durch den Geist offenbahrten Wohltaten Gottes zu dem vom Geist belehrten und durch den Geist zum Reden ermächtigten Apostel führte, schlieszt sich nun bei dem Hörer des Apostels, der wieder durch den Geist zu dem hier nötigen Aufnehmen befähigt ist. Auch er, dieser Hörer, gehört in seiner Existenz in das Wunder hinein, das hier Ereignis ist". ${ }^{15}$ M.a.w., terwijl de oude vrijzinnigheid de inspiratie subjectiveert en relativeert, gaat de Neo-orthodoxie ze actualiseren. Het is iets, dat telkens weer plaats vindt. Toch is in beide gevallen het resultaat, dat de Bijbel niet meer dan een gewoon menselijk boek is. Voor de vrijzinnige is het een boek met religieuze ervaringen. Voor de neo-orthodoxe is het een getuigenis der openbaring. In beide gevallen echter moet dit boek onderscheiden worden van het Woord Gods zelf. Het is een menselijk document en als zodanig is het beperkt en feilbaar.

c. Achter de klassieke of orthodoxe Schriftbeschouwing ligt een heel andere opvatting van inspiratie. Misschien zouden we het zo kunnen omschrijven. Inspiratie is die activiteit van de Heilige Geest, waarbij Hij bepaalde personen, die Hij voorbereid heeft door de providentiele ordening van hun hele leven, in hun spreken en schrijven maakt tot getuigen van Gods zelfopenbaring in Jezus Christus. In dit hele proces leidt Hij hen zo, dat wat zij spreken of schrijven niet maar een menselijk woord is (hoe diep en hoe subliem ook), maar inderdaad het Woord van God voor hun luisteraars of lezers. Zoals U ziet, gebruiken ook wij het woord ,getuigen", dat zo 'n grote rol speelt in de Barthiaanse Schriftbeschouwing. Maar wij gebruiken het in een heel andere zin. Bij Barth betekent dit woord begrenzing. De Bijbel is niet openbaring, maar alleen maar een mensenwoord. Het wijst alleen maar naar de openbaring heen. In onze omschrijving van inspiratie gebruiken we het heel anders, nl. in de volle Nieuw Testamentische zin van oog- en oorgetuigen. In het Nieuwe Testament betekent dit woord altijd: je kunt op deze getuigen vertrouwen, want ze hebben wat ze vertellen met hun eigen ogen gezien en met hun eigen oren gehoord. Ja, hun getuigenis is zo betrouwbaar, dat Jezus zich zelf met dit getuigenis kan identificeren. „Wie naar u hoort, hoort naar Mij; wie u verwerpt, verwerpt Mij; en wie Mij verwerpt, verwerpt $\mathrm{Hem}$, die $\mathrm{Mij}_{\mathrm{j}}$ gezonden heeft" (Luk. $10: 16){ }^{10}$ 


\section{De Bijbel: het Woord van God}

Met opzet hebben we op dit alles grote nadruk gelegd. We zijn er zeker van, dat er in dit alles niets nieuws ligt voor de meeste van onze lezers. En toch is het o.i. nodig om dit alles scherp en duidelijk te stellen, want dit is het enige kader, waarin we over het gezag van de Schrift kunnen spreken. Tegenwoordig is er ook in de Gereformeerde theologie een tendenz om van de andere kant te beginnen. Men begint dan met een historische analyse van de Bijbel en probeert zo tot een leer der Schrift te komen. O.i. is dit onmogelijk. We zijn het volkomen eens met Bavinck, als deze schrijft dat ,wie zijn leer van de Schrift afhankelijk maakt van het historisch onderzoek naar haar wording en structuur, begint reeds met het getuigenis der Heilige Schrift te verwerpen en staat dus niet meer in het geloof aan die Schrift". ${ }^{17}$ Men kan het ook zo zeggen: op historische wijze komt men nooit tot een theologische leer der Schrift. Men komt hoogstens tot een historische leer, maar nooit tot een theologische. „Historisch-critisch onderzoek kan een helder inzicht geven in het ontstaan, de geschiedenis, de structuur van de Schrift, maar leidt nooit tot een leer, tot een dogma de $S$. Scriptura. Dit kan uiteraard slechts gebouwd worden op een getuigenis der Schrift aangaande zichzelve"." Dit is inderdaad het enig juiste uitgangspunt en alleen binnen het kader van dit zelfgetuigenis kan men dan verder spreken en de verschillende aspecten van de Schrift onderzoeken.

Er kan o.i. geen twijfel over bestaan, dat het zelfgetuigenis van de Schrift is, dat we in deze verzameling geschriften te maken hebben met het Woord van God. De Bijbel is het Woord van God. In de omschrijving, die we boven gaven, zeiden we, dat de Heilige Geest de auteurs op zodanige wijze leidde, dat wat zij spraken of schreven ook inderdaad en ten volle het Woord van God is. Deze formulering was met opzet gekozen. Soms leest men het ook heel anders in Gereformeerde werken. Men zegt dan bv., dat inspiratie betekent, dat de auteurs zonder enige fouten schreven. Zo zegt Charles Hodge het bv. in zijn ,Systematic Theology': „The design of inspiration is to render certain men infallible as teachers". „The object or design of inspiration is to secure infallibility in teaching"." Nu geloven wij ook wel, dat dit een van de aspecten van inspiratie is, maar het is toch niet juist om het voorop te stellen, alsof dit het primaire doel van inspiratie was. Hoe belangrijk onfeilbaarheid ook mag zijn, het is niet het voornaamste aspect. Als zodanig is het alleen maar het formele aspect van de Bijbel. In zijn Gereformeerde Dogmatiek maakt Bavinck de volgende belangrike opmerking. "De Schrift is het Woord Gods; zij bevat het nie alleen maar zij is het. Maar het formele en materiele element mag in deze uitdrukking niet vaneen gescheiden worden. Inspiratie alleen en op zichzelve zou een geschrift nog niet tot woord Gods maken in schriftuurlijken zin. Al ware een boek over aardrijkskunde bijvoorbeeld geheel en al ingegeven en in de meest letterlijken zin van woord tot woord gedicteerd, daardoor werd het nog niet theopneust 
in den zin van 2 Tim. $3: 16$. De Schrift is het woord Gods, omdat de Heilige Geest in haar van Christus getuigt, omdat zij den Logos ensarkos tot stof en inhoud heeft": :

M.a.w., het is de inhoud, die de Bijbel tot Woord van God maakt. Het is ook de inhoud, die de Bijbel gezaghebbend maakt, met een gezag dat niet minder dan goddelijk is. Laat me het duidelijk maken met een voorbeeld. Toen ik een jongen van een jaar of zestien, zeventien was, geloofde ik, dat de hele Bijbel „from cover to cover" onfeilbaar was en zonder enige dwaling. Opgevoed in een Christelijk gezin twijfelde ik daar nooit aan. En toch had die ,onfeilbare' Bijbel geen werkelijk gezag over mij. Mijn hart bleef koud. Ik geloofde zijn boodschap niet."

\section{Gezag en onfeilbaarheid}

Het voorafgaande betekent niet, dat we een tegenstelling willen scheppen tussen gezag en onfeilbaarheid. Ook willen we helemaal niet beweren, dat onfeilbaarheid er niet toe doet. Integendeel, we geloven, dat het heel belangrijk is. Maar waar het ons omging en omgaat is, dat we de dingen in hun juiste perspectief moeten zien. Of anders gezegd, we moeten onze prioriteiten zuiver stellen. Het gezag van de Bijbel staat en valt niet met haar onfeilbaarheid. Ook dit is heel vaak zo gesteld door Gereformeerde auteurs. Men vindt het bv. heel sterk in de Amerikaans-Gereformeerde Princeton traditie. Charles Hodge bv. schrijft: „If the Scriptures are a revelation from God, they must be received and obeyed; but they cannot be thus received without attributing to them divine authority, and they cannot have such authority without being infallible in all they teach". "2z Zijn zoon, A. A. Hodge, zegt in dezelfde geest, dat de geschriften van de Bijbelschrijvers zijn ,,an authoritative revelation to us from God, endorsed by him, and sent to us as z rule of faith and practice, the original autographs of which are absolutely infallible, when interpreted in the sense intended, and hence are clothed with absolute divine authority". "In zijn bekende werk ,The Inspiration and Authority of the Bible' geeft B. B. Warfield telkens weer prioriteit aan onfeilbaarheid of betrouwbaarheid (,trustworthiness'), door onfeilbaarheid eerst te noemen en pas daarna van gezag te spreken. ${ }^{24}$ In zijn definitie van inspiratie zegt J. Gresham Machen, dat de Bijbelschrijvers ,received a blessed and wonderful and supernatural guidance and impulsion by the Spirit of God, so that they were preserved from the errors that appear in other books and thus the resulting book, the Bible, is in all its parts the very Word of God, completely true in what it says regarding matters of fact and completely authoritative in its commands". ${ }^{25} \mathrm{E}$. J. Young gebruikt dezelfde approach in zijn boek ,Thy Word is Truth'. „If the Bible is not infallible, we can be sure of nothing". "If the Gospels are filled with minor blemishes and errors, how do we know that they do not contain greater blemishes? If in so-called minor matters they have failed us, by what warrant may we declare that in so-called major matters they are trustworthy?" "If "If the evange- 
lists were guilty of trifling errors and evidences of carelessness in so-called minor matters, we simply cannot escape the conclusion that they may have been just as careless in more important things. If the writers of the Gospels cannot even agree as to the number of those whose eyes were opened by the Lord, we may very rightly ask how we can know whether the eyes of any were opened? Since the accounts are so garbled, there may not have been any miracle performed at all"."

Persoonlijk geloven we, dat deze hele benadering, hoe goed ze ook bedoeld mag zijn, verkeerd is. In de eerste plaats is dit, zoals James Orr al gezegd heeft, ,a suicidal position”. „It is urged that unless we can demonstrate what is called the ,inerrancy' of the biblical record, down even to its minutests detail, the whole edifice of belief in revealed religion falls to the ground. This, on the face of it, is a most suicidal position for any defender of revelation to take up"." Immers ook al zouden we ontdekken, dat de Bijbel niet in elk opzicht feilloos is, dan zouden we hier toch nog de boodschap vinden van Hem, "who made superhuman claims and whose character, words and deeds attested the truth of these claims". In de tweede plaats - en dit is nog belangrijker - het is ook niet waar. In zijn boek ,Tact en Contact' heeft J. Overduin er terecht op gewezen, dat het mogelijk is, dat iemand in zijn formele Schriftopvatting heel wat verkeerde ideën heeft en toch met zijn hele hart uit het Evangelie leeft, terwijl het ook mogelijk is, dat iemand formeel de onfeilbaarheid vn de Bijbel heel sterk benadrukt en toch in werkelijkheid de inhoud van de Schrift niet in geloof geassimileerd heeft. ${ }^{: 0}$ Natuurlijk wil Overduin hier helemaal niet mee zeggen, dat onfeilbaarheid er niet toe doet. Het gaat ook hem om onze prioriteiten. Het primaire aspect van de Bijbel is het materiele aspect: haar inhoud, het feit, dat dit Gods boodschap aan ons is. En het is dit materiele aspect, dat de Bijbel ook gezaghebbend in de schriftuurlijke zin van het woord maakt.

Zo nu en dan hebben de Princeton theologen dit ook wel gezien. In een gecombineerd artikel bv., waarin ze een ,errorless Scripture' verdedigen, schreven A. A. Hodge en B. B. Warfield: „Not should we ever allow it to be believed that the truth of Christianity depends on any doctrine of inspiration whatever. Revelation came in large part before the record of it, and the Christian Church before the New Testament Scriptures. Inspiration can have no meaning if Christianity is not true, but Christianity would be true and divine, and being so, would stand, even if God had not been pleased to give us, in addition to his revelation of saving truth, an infallible record of that revelation, absolutely errorless by means of inspiration"." Hier staat en valt de Christelijke boodschap niet meer met de onfeilbaarheid van de Bijbel, maar alle nadruk valt op de inhoud. De Bijbel is de openbaring van Gods boodschap der verlossing en als zodanig heeft hij gezag.

Gezag en onfeilbaarheid zijn niet hetzelfde, noch is het ene op het andere gebaseerd. Het is correcter om van twee kanten, twee aspecten van dezelfde zaak te spreken. Beide zijn ze een aspect 
van Gods Woord. Gezag is het materiele aspect; het slaat op de inhoud, de boodschap. Onfeilbaarheid is het formele aspect; het slaat op de vorm, waarin de boodschap tot ons komt. Maar als we het zo stellen, dan is het meteen ook duidelijk, dat deze twee aspecten nooit van elkaar gescheiden kunnen worden. Ze horen onlosmakelijk bij elkaar. De een gaat net zover als de andere. Als de een begrensd is, is de andere het ook. Als de een zich uitstrekt over de hele Schrift, dan doet de andere het ook. En dit laatste is ongetwijfeld de leer van de Schrift zelf. In 2 Tim. $3: 16$, waar Paulus expliciet het feit van de inspiratie noemt, zegt hij heel duidelijk: Pasa graphe theopneustos. De ganse Schrift, in al haar delen, is geinspireerd en daarom heeft de ganse Schrift gezag. We kunnen hier geen enkele selectie toepassen. Niet alleen niet omdat we daarvoor geen criteria hebben, maar ook omdat dit rechtstreeks ingaat tegen de duidelijke ,claim' van de Schrift zelf, nl., dat ze in haar geheel (,pasa') geinnspireerd is. „The whole Bible comes to us and offers itself to us in exactly the same way, and as a whole. There is no hint, no suspicion of a suggestion that parts of it are important and parts are not. All come to us in the same form"."

\section{De aard van het Schriftgezag}

Tot zover hebben we over het Schriftgezag in het algemeen gesproken. We hebben het eenvoudig een ,goddelijk' gezag genoemd. Maar dat zullen we toch wel wat meer precies moeten definieren. We zullen de vraag moeten stellen: wat voor soort gezag is dat ,goddelijk' gezag? Wat is de aard van dat gezag? Na het voorafgaande is het duidelijk, dat hier maar een antwoord mogelijk is, nl. dat het gezag van de Schrift haar gezag als de boodschap van God is. We kunnen ook zeggen, dat het een openbaringsgezag is.

De geschriften, waaruit onze Bijbel bestaat, zijn niet aan de kerk gegeven om ons alle mogelijke informatie te geven over allerlei interessante dingen of werkelijkheden, waar we anders niets van zouden weten. Bv. informatie over God, over engelen en demonen, over een bovennatuurlijke wereld, over het hiernamaals, ens. Ongetwijfeld ontvangen we hierover inlichtingen, want de Bijbel spreekt over al deze zaken, maar deze informatie is altijd geheel bepaald door het bijzonder doel, waarvoor de Bijbel zelf is gegeven. Dit doel is, dat God zich zelf openbaart, zijn verlossingsplan en ook zijn gebod voor ons leven. Anders gezegd, God openbaarts zich als de Vader van onze Here Jezus Christus, zijn vleesgeworden Zoon, die ons niet alleen gaat verlossen, maar ons ook inderdaad verlost heeft. Met opzet formuleren we het op deze eigenaardige wijze: „die ons gaat verlossen", dat is het Oude Testament, prospectieve openbaring; ,die ons ook inderdaad verlost heeft, dat is het Nieuwe Testament, retrospectieve openbaring. En in het midden staat Jezus Christus zelf, die de openbaring van God is. Zo vinden we het ook in de oude geloofsbelijdenissen van de kerk. Jezus Christus wordt genoemd in het middelste artikel, dat tegelijk het langste is. 
Dit is inderdaad de boodschap van de Bijbel. Dit is wat de Bijbel proclameert. Dit is ook de wijze waarop de oude kerk het verstaan heeft, zoals blijkt uit haar belijdenissen, waarin ze het antwoord des geloofs uitsprak. Zowel de Apostolische Geloofsbelijdenis als de Belijdenis van Nicea bestaan uit drie artikelen: over God de Vader en de schepping; over God de Zoon en de verlossing; over God de Heilige Geest en de heiligmaking. In alle drie artikelen gaat het over het werk van de ene God en in alle drie artikelen is het het werk van de God, die zich geopenbaard heeft in Jezus Christus. Zelfs in het eerste artikel, dat handelt over God de Vader en de schepping, gaat het over God-in-Christus. De Heidelberger Catechismus legt dit artikel zo prachtig uit in de volgende woorden: „Dat de eeuwige Vader van onze Here Jezus Christus, die hemel en aarde, met al wat er in is, uit niet geschapen heeft, die ook door zijn eeuwige raad en voorzienigheid ze nog onderhoudt en regeert, om zijns Zoons Christus' wille mijn God en mijn Vader is..." (Zondag 9). Vanwege deze ,Christ'-elijke context en inhoud van ons geloof is het ook geen wonder, dat het tweede artikel het langste is. Het is "the heart of the Christian confession... The second article does not just follow the first, nor does it just precede the third; but it is the fountain of light by which the other two are lit". In hetzelfde verband wijst Barth er ook op, dat ,it is believed that the original Christian confession consisted of three words, ,Jesus Christ (is) Lord', to which were only later added the first and third articles. This historical event was not arbitrary. It is also materially significant to know that historically the second article is the source of the whole. A Christian is one who makes confession of Christ. And Christian confession is confession of Jesus Christ the Lord"."

Deze historische ontwikkeling en structuur van de belijdenis komt precies overeen met de bedoeling der Schrift zelf. De Schrift heeft maar een doel: ons tot geloof in deze God brengen en tot geloof in de verlossing in zijn Zoon door de kracht van de Heilige Geest. Men zou dit de ,scopus' van de Heilige Schrift kunnen noemen. Het komt heel duidelijk uit in het slot van het Evangelie naar Johannes: ,Jezus heeft nog wel vele andere tekenen voor de ogen zijner discipelen gedaan, die niet beschreven zijn in dit boek; maar deze zijn geschreven, opdat gij gelooft, dat Jezus is de Christus, de Zoon van God, en opdat gij gelovende, het leven hebt in zijn naam" (Joh. 20:30, 31). Hetzelfde vinden we in de bekende passage uit 2 Tim. 3, waar Paulus spreekt van het ingegeven-zijn van de ganse Schrift (of van elk schriftwoord, N.Vert.), in vers 16. Helaas wordt in het gebruik dit woord vaak uit zijn verband geïsoleerd en wordt het min of meer op zichzelf gesteld en bezien. In werkelijkheid echter ligt dit woord ingebed in uitspraken over dezelfde ,scopus' van de Schrift. In het voorafgaande vers spreekt Paulus immers over ,de heilige schriften, die u wijs kunnen maken tot zaligheid door het geloof in Jezus Christus" (vers 15). En onmiddellijk na de woorden over het ingegeven-zijn van de Schrift lezen we, dat deze Schrift „nuttig (is) om te onderrichten, te weerleggen, te ver- 
beteren en op te voeden in de gerechtigheid, opdat de mens Gods volkomen zij, tot alle goed werk volkomen toegerust"' (verse 16, 17).

\section{Een boodschap in verschillende vormen}

Ook het voorafgaande was nog steeds te algemeen. We zullen de aard van het Schriftgezag nog verder moeten proberen te definieren, maar dan wordt het meteen ook veel moeilijker.

Laten we beginnen met het feit, dat deze boodschap van God tot ons komt in verschillende vormen. De Bijbel bevat heel wat verschillende literaire genres. Er zijn boeken, die hoofzakelijk geschiedenis bevatten. Andere bevatten lange stukken wetgeving. In weer andere vinden we de zgn. chokma, de wijsheid literatuur. Weer andere zijn hoofzakelijk profetisch. Er zijn boeken bij die hoofdzakelijk leerstellig en/of paranaetisch zijn. In onze tijd wordt veel aandacht aan dit verschijnsel van de verschillende literaire genres besteed. Dat geldt bv. van de R.K. theologie. Vooral na de bekende encycliek ,Divino Afflante Spiritu' van 1943 heeft de R.K. bijbelwetenschap zich hier hoe langer hoe meer op geconcentreerd. Ook in Gereformeerde kring wordt er hoe langer hoe meer aandacht aan gegeven. Ik denk bv. aan de geschriften van prof. dr. J. L. Koole. Ongetwijfeld is dit alles niet alleen geoorloofd, maar ook erg belangrijk, want we zullen dit verschijnsel in rekening moeten brengen, als we de Bijbel goed willen verstaan.

Ook hier moeten we dan beginnen met te zeggen, dat al deze verschillende genres uiteindelik een en hetzelfde doel hebben, $\mathrm{nl}$. de grote werken Gods te verkondigen. Doordat de Bijbel primair over die daden Gods handelt, is het geen wonder, dat de zgn. historische boeken zo 'n grote plaats innemen. Zowel het Oude als het Nieuwe Testament beginnen met historische boeken. Het Christelijk geloof is niet een vorm van filosofie, noch is het een systeem van moraal, maar het is gebaseerd op historische feiten. Alles hangt dus van de vraag af, of die feiten ook werkelijk gebeurd zijn. Als het alleen maar mythen zijn, dan heeft de Bijbelse boodschap haar fundering verloren. De Bijbelschrijvers zelf leggen er grote nadruk op, dat we met werkelijke feiten te maken hebben. Petrus schrijft: „Wij zijn geen vernuftig gevonden verdichtsels nagevolgd, toen wij u de kracht en de komst van onze Here Jezus Christus hebben verkondigd, maar wij zijn ooggetuigen geweest van zijn majesteit. Want Hij heeft van God, de Vader, eer en heerlijkheid ontvangen, toen zulk een stem van de hoogwaardige heerlijkheid tot Hem kwam: Deze is mijn Zoon, mijn geliefde, in wie Ik mijn welbehagen heb. En deze stem hebben ook wij uit de hemel horen komen, toen wij met Hem op de heilige berg waren" (2 Petr. 1 : 16-18). Als Paulus de werkelijkheid van de opstanding moet verdedigen tegenover hen, die haar vergeestelijken, beroept hij zich op een indrukwekkende reeks getuigen aan wie Christus na zijn opstanding verschenen is: Cephas, de twaalve, meer dan vijfhonderd broeders tegelijk „van wie het merendeel thans nog in leven is" (m.a.w., als jullie mij niet geloven, ga dan maar naar Galilea, waar je ze nog bij honderden 
kunt ontmoeten), Jacobus, al de apostelen en tenslotte zijn eigen ervaring op de weg naar Damascus (1 Cor. $15: 5-8)$. Vooral in het Evangelie naar Johannes vinden we telkens weer een sterke nadruk op het ,getuigenis'-karakter van de boodschap. Dit is juist daarom zo merkwaardig, omdat in dit Evangelie ook zo 'n sterke nadruk gelegd wordt op het feit, dat dit getuigenis gericht is op het geloof. Er is ,geen evangelist die ten aanzien van de heilsfeiten zulk een realistische, antidocetische, aanschouwelijke en tot in de onderdelen preciese weergave van het door de apostelen doorleefde geeft als Johannes, vgl. bijv. 19 : 25 e.v.; 19 : 33 e.v.; 20 : 1 e.v.; $3-9,24$ e.v. Hierbij komt immers voor het geloof alles aan op het geschied zijn en op het zó-geschied zijn, 19:35. Niet de volledigheid, niet de historische interesse in al wat geschied is, maar de zekerheid, dat het geloof zich kan verlaten op hetgeen aangaande dit gebeuren verhaald en beschreven is, vormt de kracht en de inhoud van het getuigenis, Joh. 20:30, 31". as

Maar dan moeten we er onmiddellijk weer aan toevoegen, dat het nooit om ,blote' feiten gaat. De Bijbel is niet een gewoon geschiedenisboek. Het is niet een boodschap, die ons van allerlei informatie voorziet, maar ze roept ons tot bekering en tot geloof. Juist in het Evangelie van Johannes komt dat weer zo sterk uit. Dit Evangelie spreekt niet alleen met grote nadruk over de historiciteit van de feiten, maar het is even nadrukkelijk in zijn spreken over de heilsbetekenis van deze feiten. Als Johannes bv. vertelt van de speer, die Jezus' zijde doorboorde, voegt hij er aan toe: „En die het gezien heeft, heeft er van getuigd, en zijn getuigenis is waarachtig en hij weet, dat hij de waarheid spreekt". Twee dingen vallen hier op. Aan de ene kant is er de sterke nadruk op de feitelijkheid. Hij beroept zich, als in een eed, op de verheerlijkte Christus zelf. ${ }^{36} \mathrm{Ja}$, het is werkelijk zo gebeurd. Maar aan de andere kant is er toch meteen ook de zware nadruk op het heilskarakter van wat hier beschreven wordt. Het doel is: „omdat ook gij gelooft”. Het is niet „enkel de historiciteit van Jezus' doorstoken zijn, maar de heilrijke betekenis van zijn dood, die deze mededeling tot ,getuigenis' maakt". Deze beide componenten keren telkens weer terug in het Evangelie naar Johannes. Ze horen bij elkaar en zijn voortdurend op elkaar betrokken.

Dit alles is van de grootste betekenis voor ons verstaan van het gezag der Schrift. Het wijst er ons op, dat we de Bijbel op de juiste manier moeten lezen en er om de juiste antwoorden moeten zoeken. Bavinck zei indertijd al: „Met de inhoud hangt ook ten nauwste de bedoeling en de bestemming der Schrift samen. Alwat te voren geschreven is, is tot onze lering geschreven. Het strekt tot lering, wederlegging, verbetering, onderwijzing, die in de rechtvaardigheid is, opdat de mens Gods volmaakt zij, tot alle goed werk volmaakt toegerust. Het dienst om wijs te maken tot zaligheid. De Heilige Schrift heeft een door en door religieus-ethische bestemming. Zij wil geen handboek zijn voor de verschillende wetenschappen. $\mathrm{Zij}$ is principium alleen voor de theologie en verlangt, dat wij haar theologisch lezen en onderzoeken zullen. $\mathrm{Bij}$ al de vakken, die om 
de Schrift zich groeperen, moet het ons te doen zijn om de zaligmakende kennis Gods. Daarvoor biedt de Schrift ons alle gegevens. In dien zin is zij volkomen genoegzaam en volmaakt": Men kan hetzelfde ook uitdrukken in de vorm van enkele centrale Nieuw Testamentische categorieën: het gaat om het kerygma, de marturia, de didache.

\section{Een ,gequalificeerd' gezag}

Ongetwijfeld betekent dit alles een qualificering van het gezag der Schrift. In orthodoxe kring kan men vaak de uitdrukking: ,absoluut' gezag horen, wat de Schrift betreft. Eigenlijk is dit een dubieuze term. In feite zou het veel beter zijn om te spreken van het ,relatief' gezag der Schrift. Natuurlijk bedoelen we dat woord niet in de zin van het moderne spraakgebruik, waar het practisch gelijk is aan relativistisch, maar we bedoelen het in de originele betekenis van ,in relatie tot'. Het gezag van de Schrift is bepaald door zijn relatie tot de inhoud en het doel van de Schrift, nl. verkondiging te zijn van Gods grote daden.

Zodra men dit uit het oog verliest, loopt men gevaar de Schrift te misbruiken, hoe loffelijk de bedoelingen overigens ook mogen zijn. Ik denk bv. aan wat dr. H. M. Morris schrijft in zijn boek ,Studies in the Bible and Science'. Hij zegt daar o.a., dat hoewel de Bijbel niet primair een wetenschappelijk boek is, hij toch „,contains scores of modern scientific truths, and no scientific errors"." Hij gelooft, dat ,there are many references which seem to reveal a modern perspective, so modern in fact that it would seem to be inexplicable apart from divine revelation"." Onder de teksten, die hij noemt is o.a. Pred. 1 : 6, waar we zouden vinden ,a striking example of modern knowledge revealed in God's Word nearly 3000 years ago"." Het verbaast ons dan ook niet dat in het voorwoord van dit boek de auteur het gezag van de Schrift als volgt omschrijft: „As the Word of God, the Bible speaks authoritatively on every subject with which it deals, not only those subjects which are mainly moral and religious, but also those associated with the physical phenomena of the world in which we live"."

O.i. is dit een totaal verkeerde benadering van de Schrift. Hier wordt de bedoeling van de Schrift drastisch veranderd. Het doel van de Schrift is niet meer, zoals Bavinck zei, ,religieus-ethisch', maar de Bijbel is hier een soort van magische steen der wijzen geworden: alles wat hij aanraakt, verandert in goud, het goud der openbaring. We geloven dat Ridderbos een veel gezondere en veel schriftuurlijker aanpak heeft, als hij van de Nieuw Testamentische apostelen schrijft (en dit geldt natuurlijk ook van de andere Bijbelschrijvers, mutatis mutandis): „De apostelen als de geïnspireerde herauten van het in Christus verkregen heil hebben voor de vervulling van hun taak geen deel gekregen aan de goddelijke alwetendheid, noch ook opdracht gekregen de geheimen van de natuur, de inrichting van het heelal, de problemen van de wetenschap te ontsluieren... Het Nieuwe Testament is geen openbaringsboek in die zin, dat het in 
al zijn uitspraken, direct of indirect, een antwoord bedoelt te geven op de vragen, waarvoor het menselijk leven ons stelt. Het loopt niet vooruit op de natuurlijke ontwikkeling van het menselijk geslacht of op de ontsluiting van de natuur; het corrigeert niet iedere aan een bepaalde tijd geboden voorstelling over de inrichting van het heelal en hetgeen daarin plaats vindt, evenmin als het de aanhalingen uit de Septuaginta op hun overeenstemming met de Hebreeuwse tekst controleert of iedere door Paulus aan zijn rabbijnse opvoeding ontleende begripsbepaling autoriseert"."

Op zich zelf is dit alles niet nieuw. Calvijn zei iets dergelijks al in zijn commentaar op Genesis. „To my mind, this is a certain principle, that nothing is here treated of but the visible form of the world. He who would learn astronomy, and other recondite arts, let him go elsewhere... For Moses here addresses himself to our sense, that the knowledge of the gifts of God which we enjoy may not glide away... By this method... the dishonesty of those men is sufficiently rebuked who censure Moses for not speaking with greater exactness. For as it became a theologian, he has respect to us rather than to the stars... Moses wrote in a popular style things which, without instruction, all ordinary persons, endued with common sense, are able to understand; but astronomers investigate with great labour whatever the sagacity of the human mind can comprehend" (Commentaar op Gen. $1: 6,15,16$ ).

Het grote verschil met vroeger is, dat we ons hier vandaag meer bewust van zijn. In de laatste honderd jaar is het menselijk aspect van de Schrift veel intensiever bestudeerd, en ook als Gereformeerden kunnen we daar niet alleen niet aan ontkomen, maar we moeten er dankbaar voor zijn en er onze winst mee doen. In dit verband willen we ook nog even op de zgn. literaire genres terugkomen. Velen zijn daar erg bang voor. Natuurlijk kan het niet ontkend worden, dat er gevaarlijke kanten aan zitten. Men kan ook literaire genres aanvaarden, die vreemd zijn aan het wezen der Schrift, bv. een mythische of mythologische verklaring van de eerste hoofdstukken van Genesis. Maar de mogelijke, en soms zelfs zeer reële gevaren, mogen ons niet brengen tot een ontkenning van de aanwezigheid van verschillende genres. We hebben ons hier vroeger wel eens te gauw vanaf gemaakt en de Schrift soms veel te veel vanuit onze modern-westers gezichtspunt gelezen. Neem bv. het besluit van de bekende Synode van Assen (1926) over de uitleg van de eerste hoofdstukken van Genesis. Hier werd apriori een bepaalde exegese vastgelegd, zonder dat er voldoende aandacht besteed was aan de vraag, wat soort van literatuur we hier hebben. Het is goed en noodzakelijk, dat deze vragen opnieuw onder ogen worden gezien. We mogen nooit uit het oog verliezen, dat wij onze opinies mogen hebben t.a.v. de vraag wat wel en wat niet door God in zijn openbaring gebruikt kan worden, maar dat het veel beter is om maar rustig na te gaan, wat God in werkelijkheid gebruikt heeft.

We geven onmiddellik toe, dat hier veel problemen liggen. Maar het is toch zeker onjuist om onmiddellijk maar klaar te staan met 
de uitspraak: nu heeft de Schrift geen gezag meer. Dan binden we het gezag van de Schrift aan een bepaalde interpretatie. Natuurlijk moeten we oppassen voor dualisme. Men kan de dingen ook zo interpreteren, dat er geen boodschap meer overblijft. Men kan zo gaan onderscheiden tussen boodschap en verpakking, dat we vorm en inhoud uit elkaar gaan halen. Een voorbeeld daarvan vinden we in dr. Kuitert's stelling, dat Paulus in Rom. 5 bezig is te werken met rabbijnse leermodellen. Zowel in wat Paulus in Rom. $5: 12$ e.v. als in 1 Tim. $2: 14$ zegt, hebben we te maken met ,het typische Schriftgebruik van de rabbijnen... Paulus gaat met het Oude Testament om zoals de rabbijnen dat doen: hij gebruikt de Schriftplaatsen en teksten (een heel kras voorbeeld is Gal. 4 : 21-31!) voor zijn eigen doel. Het enige verschil met de rabbijnen, zo zouden we kunnen zeggen, is juist dat doel van Paulus: hij wil met behulp van de typisch rabbijnse Schriftuitleg... de betekenis van Jezus als Messias duidelijk maken". Het gaat in Rom. 5 uiteindelijk alleen maar om de boodschap van Jezus. „Daarom verandert aan het geloof ook niets als Adam niet een historisch persoon blijkt te zijn. De werkelijkheid van Jezus wordt niet gedragen door wat de bijbel over Adam zegt, maar staat voor zich zelf"." O.i. gaat het hier allemaal wel wat erg vlot. Afgezien nog van de vraag of de Rabbijnen werkelijk wel zo on-historisch dachten (werkten ze met een of-of, d.w.z., of historisch of leermodel; of werkten ze veel harmonischer met een zowel-als, d.w.z., zowel historisch als leermodel? Ik dacht dat Gal. 4 : 21-31 juist hiervan een bewijs was!), op deze wijze is men bezig Paulus zelf iets heel anders te laten zeggen dan hij in werkelijkheid zegt. Natuurlijk heeft Kuitert gelijk, als hij zegt, dat voor Paulus de boodschap van Jezus niet afhangt van de boodschap van Adam. Dat is, dacht ik, nog nooit zo gezegd door de Gereformeerde theologie. Maar de vraag, die Paulus bezighoudt is, hoe de boodschap van Christus samenhangt met die van Adam (en dus van ons allemaal). Als men dit niet meer vasthoudt, als er geen historische samenhang is tussen Jezus en Adam, en tussen Adam en Jezus, dan is Paulus' hele betoog zinloos. Dan laat men Paulus in feite iets heel anders zeggen dan hij in werkelijkheid zegt. Om het maar cru te zeggen: dan laat men Paulus buikspreken en daarmee tast men wezenlijk het gezag der Schrift aan. Hoewel er een zeker recht ligt in de onderscheiding van vorm en inhoud (of wil men, verpakking en boodschap), men mag nooit uit het oog verliezen, dat de inhoud (of boodschap) tot ons komt in deze vorm (verpakking) en dat men ze nooit van elkaar los kan maken. We kunnen onderscheiden, maar nooit scheiden. Elke scheiding hier betekent, dat men de boodschap zelf aantast.

Als Gereformeerden zullen we altijd moeten blijven vasthouden, dat de hele Bijbel, zowel wat vorm als inhoud betreft, het Woord Gods is. Maar dan zullen we toch tegelijk ook moeten beseffen, dat de Bijbel Gods Woord is op de wijze waarop God het bedoeld heeft. Hij is Gods Woord als verkondiging, als getuigenis, als lering van Gods grote verlossing in Jezus Christus. Wie meer van de Bijbel vraagt, vraagt meer dan God ons gegeven heeft. Dit geldt 
niet alleen tegenover Fundamentalisten zoals $H$. M. Morris, maar tot op zekere hoogte ook tegenover Gereformeerde theologen zoals Warfield. Neem bv. wat hij schrijft over het gezag van de Bijbel. "In the Saviour's view the indefectible authority of Scripture attaches to the very form of expression of its most casual clauses. It belongs to Scripture through and through, down to its most minute particulars, that it is of indefectible authority... Both $\mathrm{He}$ and they (i.e., the N.T. writers) make their appeal indifferently to every part of Scripture, to every element in Scripture, to its most incidental clauses as well as to its most fundamental principles, and to the very form of its expression"." Warfield schrijft deze woorden in een bespreking van Joh. 10:35 - ,de schrift kan niet gebroken worden". Ongetwijfeld is dit een belangrijke uitspraak voor de leer der Schrift en we aanvaarden dit woord als Gods eigen woord over zijn Woord. Jezus erkent en handhaaft hier het gezag van het Oude Testament in zijn dispuut met de tegenstanders. Warfield heeft dan ook gelijk, als hij spreekt van het ,indefectible' of ,irrefragable' gezag, dat Jezus hier aan de Schrift toekent. Maar als hij dan verder gaat en spreekt van ,every element of Scripture" en ,the very form of expression of its most casual clauses", dan gaat hij toch beslist verder dan wat Jezus hier zegt. We kunnen ook zeggen, dat het maar gedeeltelijk waar is. In een absolute zin (en zo wordt het toch door Warfield zelf bedoeld) is het niet waar. Jezus en de apostelen beriepen zich niet op „every element in Scripture". Ze beriepen zich bv. nooit op een element, dat in de sfeer van de wetenschap, de astronomie, de chronologie, enz., ligt, alhoewel zulke elementen toch telkens in het Oud Testament gevonden worden. Hun beroep was altijd op het openbaringsaspect van het Oude Testament. Voor hen was het Oude Testament het boek van de openbaring van God Zelf en van zijn plan der verlossing, en als zodanig gebruikten ze het.

Men mag ook niet zo vlot spreken van "the most incidental clauses", zoals Warfield doet. Men mag dit zeker niet doen met betrekking tot Ps. 82, die Jezus aanhaalt in zijn discussie met de Farizeën. Het hart van deze discussie is Jezus' claim, dat Hij de Zoon van God is. Ter ondersteuning van deze claim en tegelijk in afwijzing van de beschuldiging van Godslastering geuit door zijn tegenstanders, beroept Jezus zich op het woord ,goden' in Ps. 82. Maar dit woord is geenszins ,casual' of ,incidental' in deze psalm, integendeel, het is centraal en fundamenteel. God richt zich tot de rechters en bestraft hen vanwege hun onrechtvaardigheid, die juist daarom zo erg is, omdat ze ,elohim', d.w.z., vertegenwoordigers van God zelf zijn. Het is duidelijk, dat juist daarom het woord ,goden' het centrale begrip in de psalm is. Men kan ook zeggen, dat het het openbaringselement in deze psalm is. Vandaar ook, dat juist dit ene geval zo 'n goede illustratie is van de wijze, waarop Jezus en zijn apostelen het Oude Testament gebruikten. Ze citeerden de woorden en zinnen nooit zo maar wat, los van hun verband (zoals dit zo vaak door de rabbijnen gedaan werd), maar hun aandacht was geconcentreerd op de openbaringsinhoud, en dat binnen het 
openbaringskader. De primaire boodschap van de tekst is altijd centraal en deze boodschap bepaalt het gezag van het Schriftwoord, dat geciteerd wordt.

\section{Nog meer beperkingen}

We moeten nog wat dieper ingaan op de ,grenzen' en ,beperkingen' van het gezag der Schrift. Persoonlijk zijn we er zo langzamerhand wel van overtuigd, dat we daar in het verleden niet genoeg recht aan gedaan hebben. Theoretisch erkenden we het wel, maar practisch kwam er vaak veel te weinig van deze erkenning terecht. En toch staan deze dingen zo duidelijk in de Schrift zelf.

In de eerste plaats is er het feit, dat de Bijbel geschreven is door mensen. Petrus schrijft, dat ,door de Heilige Geest gedreven, hebben mensen van Godswege gesproken" (2 Petr. $1: 21$ ). Als we deze uitspraak in haar verband bezien, dan ligt ongetwijfeld de nadruk op het feit dat deze mensen door de Heilige Geest gedreven waren en daarom niet hun eigen boodschap brachten, maar ,van Godswege" (apo theou) spraken. Toch mogen we niet verontachtzamen, dat Petrus ook duidelijk zegt, dat het ,mensen' waren, die van Godswege gesproken hebben. Daar ligt ook een element van beperking in. In zijn commentaar op dit vers schrijft Michael Green: „Men spoke: God spoke. Any doctrine of Scripture will not neglect either part of this truth. Certainly those who are convinced of God's ultimate authorship of Scripture will take every pain to discover the background, life situation, limitations, education, and so forth of the human agent who co-operated with God in its production. For revelation was not a matter of passive reception: it meant active co-operation. The fact of God's inspiration did not mean a supersession of the normal mental functionings of the human author. The Holy Spirit did not use instruments; He used men". " Het is interessant, dat Green in dit citaat ook het woord ,limitations' gebruikt. We geloven, dat dit volkomen juist is. Toen God deze schrijvers als de organen van zijn openbaring gebruikte, heeft Hij ze niet boven hun gewone intellectuele en emotionele capaciteiten uitgetild, maar Hij heeft ze gebruikt zoals ze waren. Hoewel ze werden opgenomen in de macht en het werk van de Geest en de Geest zijn stempel en autoriteit verleende aan hun getuigenis, blijft het toch een feit, ,dat mensen de getuigen waren, receptief en productief, van de grote werken Gods in Jezus Christus. De Geest inspireert niet slechts tot spreken en schrijven van hetgeen Hij hun ingaf, maar Hij doet hen datgene spreken en schrijven, dat zij zelf als ooggetuigen, met hun menselijke ogen en oren gezien en gehoord hadden... Als ooggetuige-verslag blijft het menselijk, dat wil zeggen: vrucht van een apperceptie, die niet oneindig was en van een reproductie, die de perken van de menselijke bevatting en van het menselijk geheugen niet overschreed"."

Het is daarom ook niet bevreemdend, dat er ,onzekerheden' of ,oneffenheden' in de Evangelien voorkomen, bv. met betrekking tot de chronologie, preciese omstandigheden, bewoordingen, enz. 
„Niet ieder woord van Jezus bij een bepaalde gelegenheid gesproken, is op dezelfde wijze overgeleverd, niet iedere gebeurtenis met dezelfde nauwkeurigheid verhaald, niet iedere historische entourage ons met dezelfde duidelijkheid getekend". Maar dit alles doet geen afbreuk aan de duidelijkheid van de boodschap zelf. Als we de Evangelien lezen op de wijze, waarop ze bedoeld zijn, nl. als de boodschap der verlossing gebracht door de getuigen van Christus, dan is er geen enkele twijfel. Dan weten we, dat God hier tot ons spreekt en dan weten we ook wat $\mathrm{Hij}$ ons te zeggen heeft.

Het bovenstaande geldt ook t.a.v. het feit, dat de boodschap tot ons komt in de taal en cultuur van een bepaalde tijd. Soms wordt de boodschap uitgedrukt in termen, die ontleend zijn aan het wereldbeeld en de psychologie van die tijd. Voor het Oude Testament kan men hier wijzen op het tweede gebod, waar het verbod om de Here God te aanbidden in de vorm van enige schepsel wordt uitgedrukt in de terminologie van het heelal met drie ,verdiepingen'. Hetzelfde vindt men ook nog in het Nieuwe Testament, bv. in Phil. 2 : 10. Ongetwijfeld liggen hier problemen. Daar is vooral de vraag: hoe ver kan en mag men hier gaan? Sommigen zien hier het spookbeeld van Bultmann al verrijzen. Maar we mogen de moeilijkheden toch ook niet overdrijven. In bijna alle gevallen is de boodschap zelf zeer duidelijk.

De tweede beperking, die we in dit verband moeten noemen, hangt samen met het feit, dat de Bijbelboeken oorspronkelijk geschreven zijn voor een bepaalde situatie en voor bepaalde mensen in die situatie. We denken hier in het bijzonder aan de zgn. paranetische gedeelten. In de Bijbel zelf zien we, dat in de loop der heilsgeschiedenis zekere verschuivingen plaats vinden. We kunnen niet altijd bepaalde geboden of vermaningen uit een bepaalde tijd direct toepassen op een andere tijd. Een heel duidelijk voorbeeld is de Mozaïsche wetgeving. Niet alleen de zgn. ceremoniële en politiek-sociale wetten zijn hierbij betrokken, maar het geldt ook van de Dekaloog zelf. We zien bv., dat de Christelijke Kerk al vrij gauw niet meer de zevende dag als de Dag des Heren houdt, maar de eerste dag van de week, de dag van die opstanding. Nu kan déze verschuiving natuurlijk vrij gemakkelijk verklaard worden. Ze vindt haar grond in het feit, dat Jezus Christus, de beloofde Messias, gekomen is. M.a.w., de voortgang van de heilsgeschiedenis zelf laat ons duidelik zien, dat de Mozaïsche wet niet meer direct toegepast kan worden. We vinden dit nogal eenvoudig. In werkelijkheid is het natuurlijk helemaal niet zo eenvoudig. In de Nieuw Testamentische Kerk heeft men er zwaar mee geworsteld. Zelfs de apostelen hadden er eerst problemen mee. Petrus moest door de Heer zelf, via een visioen, overtuigd worden (cf. Hand. 10:9 vv; vgl. ook zijn verdediging tegenover de zgn. besnijdenis partij, $11: 1$ vv.). Paulus heeft er zijn hele leven lang over moeten vechten met de Judaīsten.

Maar we mogen niet een streep zetten bij de Mozaissche wetgeving. Hetzelfde beginsel geldt ook voor sommige Nieuw Testamentische vermaningen. Ongetwijfeld geldt het hier minder sterk, maar 
het probleem ligt er toch. Hoewel we geloven, dat we gebonden zijn aan de ethische beginselen of richtlijnen van het Nieuwe Testament, toch zijn bepaalde toepassingen van die richtlijnen in het Nieuwe Testament zelf niet bindend voor alle eeuwen. Neem bv. de Nieuw Testamentische houding tegenover de slavernij, die in die bepaalde situatie stilzwijgend wordt goedgekeurd. Of neem Paulus' gebod in 1 Cor. 11: 3 over vrouwen, die een sluier moeten dragen tijdens de publieke eredienst. Blijkbaar betekende een weigering om dit te doen in die tijd een ontkenning dat de vrouw onderworpen is aan haar man. Paulus staat daarom so 'n houding niet toe. Maar in onze tijd is de mode zozeer veranderd, dat het niet dragen van een sluier niets meer zegt t.a.v. de positie van de vrouw. ${ }^{\text {to }}$ Soms vraag ik me ook wel eens af, in hoeverre dit alles ook geldt voor de Paulinische leer, dat de vrouw moet zwijgen in de gemeente. Ongetwijfeld zitten hier nogal wat problemen aan vast, maar we kunnen aan de andere kant dit probleem ook niet verwaarlozen, als we het over deze kwestie hebben.

Natuurlijk zullen velen dit onmiddellijk weer, gevaarlijk' noemen. Ze zullen weer het spookbeeld van Bultmann zien opdagen. Ik ontken ook niet, dat hier gevaren liggen. We moeten voorzichtig zijn en mogen de Bijbel niet laten buikspreken. Maar we mogen deze vragen ook niet ontlopen. Ze hangen nu eenmaal samen met de wijze waarop de Here ons zijn Woord gegeven heeft. De fundamentele modus der openbaring is die van de Incarnatie: het Woord van God in het vlees. Dat geldt van het eeuwige Woord Gods, maar ook van het gesproken en geschreven Woord van God. Dit laatste komt altijd tot ons in het woord van mensen, die schreven voor bepaalde mensen in een bepaalde tijd en in een bepaalde situatie.

Misschien zijn we in de praktijk wel eens wat te gauw geneigd de dingen te versimplificeren. We zeggen zo vaak: „De Bijbel zegt...”, en dan denken we, dat de zaak klaar is. Maar in werkelijkheid is het natuurlijk niet zo eenvoudig en meestal voelen we, dat gauw aan, als we zien hoe anderen het verkeerd doen. Als bv. de Jehovah Getuigen zich tegen alle bloedtransfusie beroepen op Lev. $17: 11-14$ en Hand. $15: 20,29$, dan zeggen we allemaal: dat is verkeerd; dat is te simpel. M.a.w., we passen het bovengenoemde principe allemaal tot op zekere hoogte toe. Niemand van ons voelt zich blijkbaar zonder meer gebonden aan het besluit van het Apostel Convent, en dat ondanks het feit, dat de geboden van dit Convent gedekt zijn met het gezag van de Heilige Geest (cf. Hand. 15 : 28 - ,het heeft de Heilige Geest en ons goedgedacht..."), en ook ondanks het feit, dat nergens in latere gedeelten van het Nieuwe Testament deze geboden herroepen zijn. Blijkbaar beseffen we allemaal, dat dit besluit gegeven werd in een bepaalde situatie en ook alleen maar gold voor die bepaalde situatie.

Persoonlijk geloven we, dat het in werkelijkheid in de meeste gevallen niet zo erg moeilijk is. Meestal vinden we het antwoord vrij gauw, als we maar de juiste vraag stellen. We moeten altijd weer vragen: wat wordt hier gezegd, geleerd, geproclameerd? Als we die vraag stellen in de context van de hele Bijbel, dan vinden we 
meestal het antwoord vrij gauw. Dit is helemaal geen wonder, want we geloven immers met de Hervormers in de perspicuitas S. Scripturae. Deze term betekent niet, dat alles in de Bijbel simpel en doorzichtig is (cf. 2 Petr. $3: 16$ !), maar het betekent wel, dat de centrale boodschap van de Schrift onmiskenbaar duidelik is en dat we deze centrale boodschap bijna overal zonder grote moeilijkheden kunnen vinden. Dit alles betekent ook, dat we meestal de oplossing in de Schrift zelf vinden. Met de Hervormers geloven we ook in de eenheid der Schrift en handhaven we de grondregel van alle exegese en hermeneutiek: Scriptura sui ipsius interpres. Als we deze regel toepassen en de Schrift volgens de analogie des geloofs bestuderen, verdwijnen een hoop van onze problemen en komt de stem, de gezaghebbende stem van de Heer der Schrift, duidelijk door.

Veel mensen klagen: „Er staat niets meer vast tegenwoordig”. Dit lijkt me sterk overdreven. Inderdaad worden bepaalde traditionele opvattingen en verklaringen betwijfeld of bestreden. Soms is dat zeer nuttig. Traditionalisme kan een beter verstaan van die Schrift in de weg staan. We geloven toch immers in de voortgaande leiding van de Heilige Geest. Soms wordt dit alles ook gedaan op een wijze, die ik niet bewonderen kan, een wijze, die een groot gebrek aan pastorale zorg voor de kerk verraadt. In sommige gevallen is men m.i. op een verkeerde weg. Als men bv. zegt, dat er geen historische Adam is geweest, dat er geen historische val was of dat de hele historische orde schepping-val-verlossing onjuist is, dan is dit m.i. geen luisteren naar de Schrift meer, maar een heersen van bepaalde menselijke overtuigingen, gebaseerd op buitenschriftuurlijke gegevens (wetenschappelijke theorieën), over de Schrift. Maar dan troost ik me toch met één ding: Gods Woord is machtig en dit Woord zal langer spreken dan onze foute interpretaties.

\section{Aanvaarding van het gezag der Schrift}

Tenslotte nog even kort over de vraag, hoe een mens tot aanvaarding van het gezag der Schrift komt. Ook hier kunnen we niet beter doen dan luisteren naar de Hervormers, die bijzondere aandacht aan deze vraag moesten geven in hun controverse met Rome. Het antwoord van Rome was: Men moet deze Bijbel als Gods Woord aanvaarden, omdat de kerk het zegt. De Hervormers hebben deze oplossing van de hand gewezen. Ten eerste zou dit beteken, dat de Schrift afhankelijk zou worden van een menselijke instelling. Ten tweede is de kerk zelf op het woord van de apostelen en profeten gefundeerd, zoals Calvijn telkens weer aanwijst. „If the teaching of the prophets and apostles is the foundation, this must have had authority before the church began to exist".."

Het antwoord van de Hervormers zelf was dat God hier Zelf voor zorgt, en dat wel op twee manieren. Ten eerste is er het inhoudelijk gezag van de Schrift zelf als het Woord van God. Als het Woord van God is de Schrift autopistos, "self-authenticating". Calvijn schrijft: „As to their question - How can we be assured that this has sprung from God unless we have recourse to the 
decree of the church? - it is as if some one asked: Whence will we learn to distinguish light from darkness, white from black, sweet from bitter? Indeed, Scripture exhibits fully as clear evidence of its own truth as white and black things do of their colour, or sweet and bitter things do of their taste". ${ }^{.1}$ In de tweede plaats doet God het door het werk van de Heilige Geest in ons, namelijk het getuigenis en de illuminatie van de Heilige Geest. Calvijn schrijft: "Those whom the Holy Spirit has inwardly taught truly rest upon Scripture, and Scripture indeed is self-authenticated; hence it is not right to subject it to proof or reasoning. And the certainty it deserves with us it attains by the testimony of the Spirit. For even if it wins reverence for iself by its own majesty, it seriously affects us only when it is sealed upon our hearts through the Spirit. Therefore illuminated by his power, we believe neither by our own nor by any one else's judgment that Scripture is from God; but above human judgment we affirm with utter certainty... that it has flowed to us from the very mouth of God by the ministry of men. We seek no proofs, nor marks of genuineness upon which our judgment may lean; but we subject our judgment and wit to it as to a thing far beyond any guesswork ... We feel that the undoubted power of his divine majesty lives and breathes there".

De Reformatoren hebben deze twee aspecten altijd bij elkaar gehouden. Het objectieve aspect, het aspect van de Goddelijke waarheid zelf, vonden ze in de Schrift. Het subjectieve aspect, de overtuiging dat dit Gods Woord is en dat we ons hieraan moeten onderwerpen, vonden ze in het inwendig getuigenis van de Heilige Geest (testimonium Spiritus Sancti internum). In de Institutie wijdt Calvijn een hele sectie aan de stelling, dat Woord en Geest onlosmakelijk bij elkaar horen. „By a kind of mutual bond the Lord has joined together the certainty of his Word and of his Spirit, so that the perfect religion of the Word may abide in our minds, when the Spirit who causes us to contemplate God's face shines; and that we may embrace the Spirit with no fear of being deceived when we recognize him in his own image, namely, in the Word".s M.a.w. het is van begin tot einde Gods werk. God zelf neemt ons in beslag door zijn Woord en Geest. Als dat gebeurt, kunner, we niet aan Hem ontkomen. Dan moet ons opstandige hart zich buigen. Dan moet ons eigenwijze verstand toegeven. Dan doen we niet meer in zelfzucht, wat onze wil ons dicteert, maar we vragen: Heer, wat wilt $\mathrm{U}$, dat ik doen zal? En dan gebeurt het wonder. De Heer spreekt tot ons door zijn Woord. In dat Woord, geschreven door mensen, horen we zijn stem. En daardoor word dit Woord onze grote rijkdom, groter dan iets anders in de wereld. Dan zeggen we wet de auteur van Psalm 12: „De woorden des Heren zijn zuivere woorden, gedegen zilver, in een smeltoven in de aarde, zevenvoudig gelouterd" (12:6).

K. Runia.

(Gelewer tydens eeufees van Teologiese Skool 1969 te Potchefstroom voor G.T.V.). 


\section{AANTEKENINGEN}

1 J. I. Packer: ,Fundamentalism' and the Word of God, 1958, 50.

2 Cf. mijn boek: Karl Barth's Doctrine of Holy Scripture, 1962, 58 vv.

3 A. Richardson: Preface to Bible Study, 1943, 36/7.

4 B. B. Warfield: The Inspiration and Authority of the Bible, 1951, 125.

5 A.w., 118, 119.

6 A.w., 119.

7 A.w., 120. Vgl. Packer, a.w., 54 vv., 86 v.

8 Vgl. Augustine Cardinal Bea: The Word of God and Mankind, 1967, 174 vv. Vgl. ook 184 v., waar hij de leer der onfeilbaarheid verdedigt. Dit boek, dat in feite niets anders dan een uitgebreide kommentaar op de Con. stitutio de Revelatione is, is vooral ook daarom zo belangrijk, omdat Kardinaal Bea de voornaamste auteur van de Constitutie zelf was (evenals hij ook de voornaamste auteur was van de bekende encycliek van 1943, Divino Spiritu Afflante, die men de Magna Charta van de moderne bijbelstudie in die R.K. Kerk heeft genoemd.

9 John H. Leitch: Creeds of the Churches, 1963, 402.

10 A.w., 456/7.

11 Cf. Anthony T. Hanson: The Church of the Servant, 1962.

12 Op dit punt zijn Luther's opmerkingen over Gal. 1: 9 nog steeds ten volle waar en actucel: "This sentence of Paul ought to admonish us, that so many as think the Pope to be judge of Scripture are accursed. Which thing the popish schoolmen have wickedly taught, standing upon this ground: for the Church hath allowed four Gospels only: therefore there are but four: for if it had allowed more, there had been more. Now seeing the Church might receive and allow as many gospels as it would, therefore the Church is above the Gospel. A goodly argument forsooth. I approve the Scripture, ergo, I am above the Scripture. John the Baptist acknowledges and confesses Christ and points to him with his finger, therefore he is above Christ. The Church approves the Christian faith and doctrine, therefore the Church is above them. For the overthrowing of this their wicked and blasphemous doctrine thou hast here a plain text like a thunderbolt, wherin Paul subjects both himself and an angel from heaven, and doctors upon earth, and all other teachers and masters whatsoever under the authority of Scripture. For they ought not to be masters, judges, or arbiters, but only witnesses, disciples, and confessors of the Scripture, whether it be the Pope, Luther, Augustine, Paul or an Angel from heaven. Neither ought any doctrine to be taught or heard in the Church besides the pure word of God; that is to say, the holy Scripture. Otherwise, accursed be both teachers and hearers, together with their doctrine" (ad loc.).

John Huxtable: The Bible Says, 1962, 25.

14 Karl Barth: Kirchliche Dogmatik, 1, 2, 563.

15 A.w., 573. Cf. mijn boek: a.w., 137 vv.

16 Vgl. mijn boek: a.w., 25 vv.

17 H. Bavinck: Gereformeerde Dugmatiek, 1, 394

18 Loc. clt.

19 Ch. Hodge: Systematic Theology, I, 155.

20 H. Bavinck: a.w., I, 414.

21 Cf. ook het verhaal van J. Overduin, in mijn boek: a.w., 164 v.

22 Ch. Hodge: a.w., 166.

23 A. A. Hodge: Outlines of Theology, 66.

24 Vgl. Warfield: a.w., 150, 158, 161.

25 Geciteerd uit een artikel in The Presbyterian Guardian. Let op de volgorde: completely true - completely authoritative.

26 E. J. Young: Thy Word is Truth, 5

27 A.w., 128

28 Loc. cit.

29 J. Orr: Revelation and Inspiration, 1952, 197/8, vgl. 213 vv.

30 J. Overduin: Tact en Contact, 1958, 105.

31 Geciteerd door Orr, a.w., 198. 
32 M. Lloyd-Jones: Authority, 1958, 35.

33 K. Barth: Dogmatics in Outline, 1958, 65.

34 Loc. cit.

35 H. N. Ridderbos: Heilsgeschiedenis en Heilige Schrift, '1955, 131.

36 Vgl. ,hij weet'. Deze nogal duistere uitdrukking wordt op verschillende manieren uitgelegd. Men ziet er een verwijzing in naar God, of Christus, of de geliefde discipel (vgl. bv. R. G. V. Tasker: John (Tyndale N.T. Commentaries), ad loc.). O.i. is de meest natuurlijke verklaring er een verwijzing naar de verheerlijkte Christus in te zien. Maar welke uitleg men er ook aan geeft, het is duidelijk bedoeld als een onderstreping van de betrouwbaarheid van wat de evangelist zegt, op grond van de oude Joodse rechtsregel, dat een getuigenis van twee of drie personen nodig is, vgl. Deut. 19: 15 . Deze regel wordt meerdere malen geciteerd in het Nieuw Testament, vgl. Matth. $18: 16 ; 2$ Cor. $13: 1$; Hebr. $10: 28$. Zie ook Openb. $11: 3$.

37 Ridderbos: a.w., 129.

38 Bavinck: a.w., 415.

39 Ridderbos: a.w., 102-147.

40 H. M. Morris: Studies in the Bible and Science, 1966, 21.

41 A.w., 25.

42 A.w., 26. Vgl, ook Hoofdstuk IX, ,Spiritual Overtones in Engineering'.

43 A.w., 7. Vgl. op dezelfde pagina: "There are numerous passages in Scripture dealing with the phenomena of hydrology, for example, and all will be found fully in accord with what is known from actual studies in this field of science".

44 Ridderbos: a.w., 115.

45 H. M. Kuitert: Verstaat gij wat gij leest?, 1968, 28.

46 Warfield: a.w., 140.

47 Michael Green: 2 Peter and Jude (Tyndale N.T. Commentaries), 1968, 91/2.

48 Ridderbos: a.w., 126.

49 W. Barclay: Letters to the Seven Churches, 1957, 75. „We must remember that when Paul spoke about women as he did in the letters to the Corinthians, he was writing to the most licentious city in the world, and that in such a place modesty had to the observed; and that it is quite unfair to wreste a local ruling from the circumstances in which it was given, and to make it a universal principle". - Dit beteken niet, dat het beginsel, dat Paulus noemt, niet meer geldig is. We willen alleen maar zeggen, dat de bijzondere toepassing van het beginsel op de toenmalige situatie met haar bijzondere gewoonten niet meer bindend is.

50 J. Calvijn: Institutes, I, vii, 2.

51 Loc. cit. Vgl. ook I, vii, 5.

52 A.w., I, vii, 5.

53 A.w., I, ix, 3. Veel Gereformeerde belijdenissen hebben Calvijn gevolgd in deze dubbele fundering van het gezag der Schrift. Vgl. de Nederlandse Geloofsbelijdenis, art. 5; de Franse Belijdenis, art. 4, 5; de Westminster Confessie, Hfdst. I, 4, 5. 